\title{
Histopathological alterations in kidney and liver of Clarias gariepinus (burchell, 1822) studied in river galma, Nigeria
}

Patrick Ozovehe Samuel ${ }^{1 *}$, John Ameh Adakole ${ }^{2}$, Bolanle Suleiman ${ }^{2}$ and Yaro J. D ${ }^{3}$

*Correspondence: ajakopatrick@yahoo.com

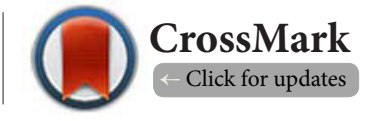

'Department of Biological Sciences, Federal University of Technology, Minna, Nigeria.

${ }^{2}$ Department of Biological Sciences, Ahmadu Bello University, Zaria, Nigeria.

${ }^{3}$ Histopathology Unit, Ahmadu Bello University Teaching Hospital, Zaria, Nigeria.

\begin{abstract}
The river ecosystem serves as ultimate sink for myriads of xenobiotic all over the world with deleterious effects on the living biota within it. Histopathological alterations in kidney and liver of the catfish Clarias gariepinus (Burchell, 1822) were studied in River Galma, Zaria Nigeria. Twenty-five samples of Clarias gariepinus were exposed to the river ecosystem at the peak of rainfall in August, 2015 for 14 days at five stations along River Galma, using the cage system. Fish samples and controls from each station were subsequently harvested and transported to the laboratory for histopathological examination of liver and kidney. Results from photomicrographs of tissues from different stations revealed varying histopathological alterations which ranged from vacuolation, constrictions, necrosis and aggregations of cells to congestion of the blood vessels. These results indicated that River Galma is witnessing pollution. This calls for ameliorative measures by relevant authorities so as to protect aquatic life as well as the public from the toxic effects of aquatic environmental pollution.
\end{abstract}

Keywords: River Galma, Eco-toxicity, Histopathological alterations, Liver, Kidney, Clarias gariepinus

\section{Introduction}

The aquatic environment is confronted with the problems of pollution chiefly orchestrated through anthropogenic activities in and around water bodies. Municipal discharges, agricultural run-offs and industrial discharges are amongst the major sources of pollutants to the aquatic ecosystems. These varied discharges are gotten from both point and non-point sources which are either discharged directly or indirectly into water or ultimately through run-offs and seepages $[\mathbf{2 5}, \mathbf{2 9}$. Organisms in aquatic environments are usually exposed to a complex mixture of chemicals including parent compound and their transformation products causing multiple damages at the organisms, population and ecosystem level, in organ function, reproductive stages and biological diversity $[10,33]$. River Galma receives variable levels of pollution from different anthropogenic activities along its banks [3]. Thus, in the last 50 years, environmental conditions have changed at an unprec- edented rate, impacting heavily on ecological processes [6].

Trace metals form the focal point of ecotoxicological studies. While some of these metals are essential in the biological activity of living organisms others are not but essential metals may be toxic for the biological activities of organisms above certain concentrations [16]. Heavy metals including both essential and non-essential elements have a particular significance in ecotoxicology, since they are highly persistent and have potential to be toxic to living organisms $[17,30]$. Heavy metals can be taken up into fish [18] either from ingestion of contaminated food via the alimentary tract or through the gills and skin [28]. Various other organs and tissues of fish have been implicated in the bio-accumulation of heavy metals. Some of these organs and tissues that have been investigated include liver and kidney $[12,19]$, muscle, bile, heart, gills [13]. High anthropogenic activities due to increase in human population have imposed various threats to aquatic biota with reference to heavy metals 
Samuel et al. Applied Scientific Reports 2017,

and their bioaccumulation potentials [18]. River Galma, being an urban river, has various types of anthropogenic activities along its banks. UNICEF/WHO (2012) observed that close to a billion people most living in the developing world do not have access to safe and adequate water. Most water sources in developing countries are polluted by both organic and chemical pollutants which include heavy elements $[11,18]$. Herbicides may enter into the aquatic environment by direct application to attack a particular pest or indirectly through atmospheric precipitation and surface run-off [34].

Eco-toxicological studies may also incorporate physicochemical parameters of the river which tell much about its quality and suitability for both humans and survival of the living biota because maximum productivity of aquatic biota depends on optimum level of physicochemical parameters [23]. The aquatic environment provides a sink for many environmental contaminants some of which have the potential to cause oxidative stress in aquatic organisms [1]. The effects of pollutants can also be seen in the histopathological alterations of the organs of fish in the polluted environment. This is because metals bio-accumulate in kidneys and other organs of fish, damaging filtering mechanisms and affecting structure and ultra-structure $[12,13]$ depending on the exposure time and dose [5]. Histopathological lesions provide a reliable, easily quantifiable index of low-level toxic stress to a broad range of environmental pollutants. Histopathological biomarkers can be used as indicators for the effects of various anthropogenic pollutants on organisms and are a reflection of the overall health of the entire population in the ecosystem [14]. The severity of damage depends on the toxic potentiality of a particular toxicant accumulated in the tissue. Therefore, exposure to polluted water may adversely affect various organs in fish which ultimately could lead to overall toxic impact on organs like gill and liver $[12,13,21]$.

Fish are particularly vulnerable to heavy metal pollution because they cannot escape from the detrimental effects of aquatic pollutants [24]. High concentration level of metal is not a necessity to produce toxic effect in the fish's body [7]. This is because heavy metal accumulation could occur in animal body tissues gradually and, overtime, can reach toxic concentration levels, much beyond permissible limits $[18,31]$. Fish, in comparison to invertebrates, are more sensitive to many toxicants and are a convenient test subject for indication of ecosystem health [35]. Fish accumulate pollutants preferentially in their fatty tissues like liver and the effects become apparent when concentrations in such tissues attain a threshold level [20]. This paper was aimed at studying the histopathological alterations in kidney and liver of the catfish Clarias gariepinus exposed in River Galma polluted ecosystem in Zaria, Nigeria.

\section{Materials and methods Study Area}

River Galma is one of the main tributaries of River Kaduna. It has its headwaters near the north western edge of the Jos Plateau and falls near the Magami village into Kaduna plains. The main tributaries of River Galma are Shika River in the middle course and the Rivers Kinkiba and Likarbu in its lower course. The Galma reservoir which is popularly called Zaria dam was constructed across the Galma River in 1975. The major land use in the catchment areas is farming and animal rearing. There are also some industrial and municipal activities (in the surrounding towns and villages such as Chikaji, Dakace and Sabon Gari areas) that produce wastes which ultimately get to the river on the long-run through run-offs and seepages. The few industries are located in Chikaji and Dakace. The sampling areas are all located in the Sabon Gari Local Government Area of Kaduna State (Figure 1).

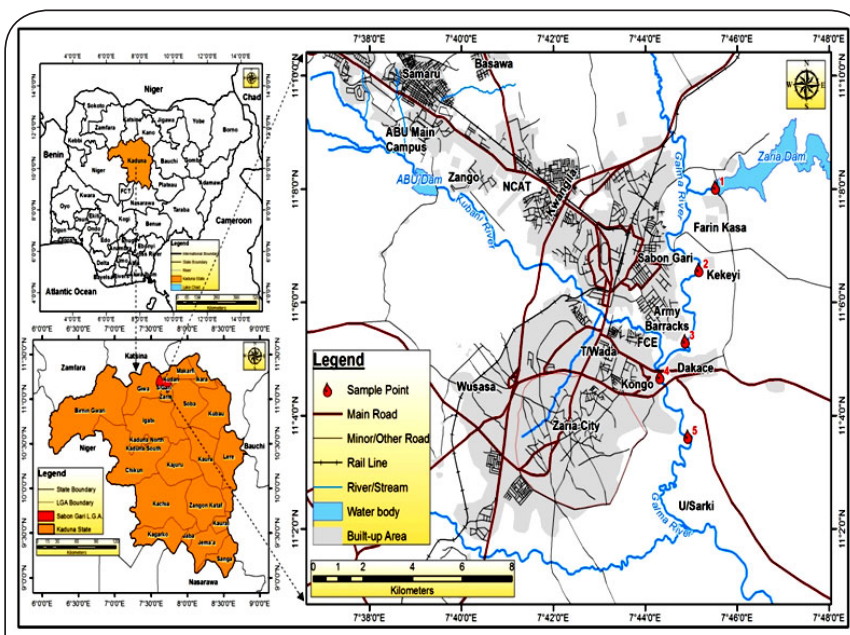

Figure 1. Map of Zaria showing Sample Stations. Modified from the Administrative Map of Zaria.

Collection and Acclimatization of Clarias gariepinus Fishes of 20-45g size range were bought from commercial farmers and acclimatized in the laboratory for a period of two weeks before they were deployed to the river.

\section{Cage Construction}

Five cages were constructed manually according to [26] for exposure of fish at stations along the river.

\section{Setting-up of the Cage for the Bioassay of Clarias garie-} pinus in River Galma

Five (5) stations were selected along the river on the basis of security and accessibility. Station 1 was located at Shika Reservoir (Zaria Dam). Shika reservoir was used as reference station because it serves as the upper course of the river and relatively located far from the industrial areas and the municipal waste load was also relatively low compared with other stations. Station 2 was located at Kakeyi village at about 2,000 meters away from Shika dam. This station receives municipal wastes and effluents and agricultural run- 
offs from the neighbouring villages and town such as Farin Kasa, Sabon Gari and Kakeyi village. Station 3 and Station 4 were located around FCE, Congo (at about 1,500 meters from Kakeyi site. Station 3 which receives municipal wastes and effluents, agricultural run-offs from some parts of Sabon Gari, Chikaji, Kakeyi and Farin Kasa villages about 500 meters from Station 4 which receives municipal wastes and effluents, agricultural run-offs from various parts of the town including Tudun Wada, PZ, Congo via Kubani stream which drains into the main at this point stream with waters from Kakeyi. Station 5 was located at Dakace village at about 1000 meters from Station 4 , and receives municipal and agricultural wastes and effluents from Dakace village and the industries in the area, as shown in Figure1. Farming and agricultural activities take place through-out the year in the area. Industries in the area include Sun Seed Company, Zaria Pharmaceutical Company and FAN Milk depot.

Five cages (one at each station) were set-up in the river for 14 days in situ bioassay in the month of August, 2015. Twenty-five samples of Clarias gariepinus (five per station) were transported to the river in a special mesh using cage system for each sampling station and then suspended into the water. The fish were left to fend for themselves within the natural ecosystem for fourteen (14) days. Their feeding was supplemented with coppens feed, $2 \mathrm{~mm}$ once at dawn after the first 24hours of exposure in the river for the remaining days of the exposure period. The cages were constantly moved from location to location on daily basis whenever the waters receded to the main river course.

\section{Histopathological Examination of Liver and kidneys sections of fish samples}

The fish samples were harvested from each station 14 days after exposure and kept in a large plastic container and transported to the laboratory. Each sample was dissected; livers and kidneys removed. These organs were preserved in 10\% formalin until analysis. The liver was dissected quickly, sliced into $3 \mathrm{~mm}$ thick slabs, and immersed in Bouin's fixative for 24 hours; it was dehydrated in successive percentages of alcohol and then embedded in paraffin wax. Sagittal sections ( $5 \mu$ of thickness) were cut and mounted on glass slides. The sections was de-paraffinized in Xylene, hydrated in ethanol and stained with hematoxylin-eosin (HE). The same procedure was used for the kidneys. The histopathological analyses were carriedout in the Histopathology Unit of Ahmadu Bello University Teaching Hospital (ABUTH), Shika. Livers and kidneys from the fish used as control were also analyzed histopathologically. Photomicrographs of livers and kidneys of Clarias gariepinus from the samples were obtained after 14 days in situ bioassay in River Gama.

\section{Results}

Histopathological damages in the kidney and liver of the fish exposed in River Galma for 14 days varied from station to station in comparison with the photomicrographs obtained prior to exposure of the kidney (Plate 1) and liver (Plate 2).

The histopathological alteration observed in Station 1 showed vacoulation and constriction of the tissues of the kidney. Similar alterations were observed in the liver of the fish exposed at the same Station but more severe in the kidney (Plates 3 and 4).

Vacoulation, constriction and aggregation of cells were also observed in the kidney and liver of the fish exposed in stations 2 and 3 with greater severity. In addition to this, necrosis and infilteration of the cells also occurred (Plates 5-8).

The histopathological damages observed in station 4 showed that in addition to other feature highlighted above,
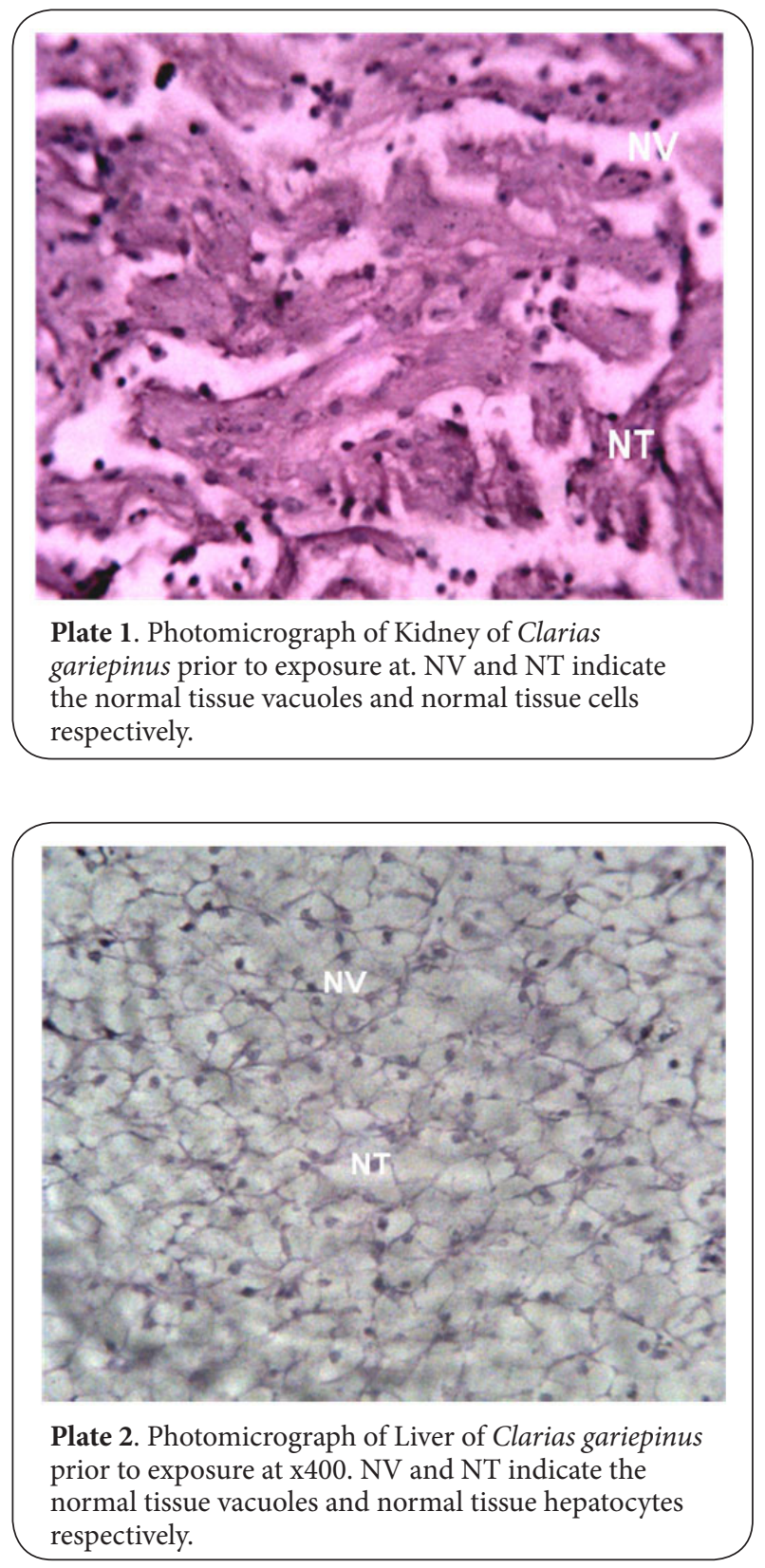


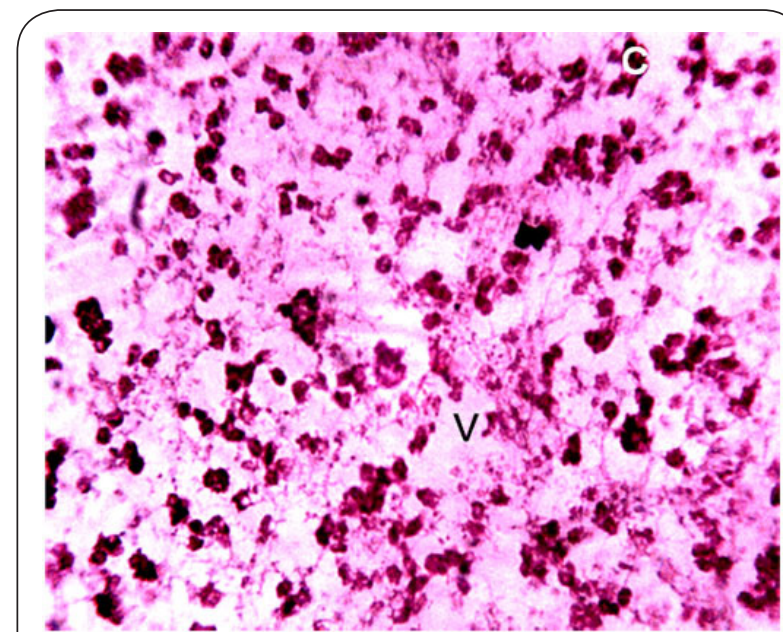

Plate 3. Photomicrograph of Kidney of Clarias gariepinus obtained from Station 1 after 14 days bio-assay in River Galma at $\mathbf{x} 400$. The letters $\mathbf{V}$ and $\mathbf{C}$ indicate severe vacoulation of the tissue and, constriction and aggregation of cells respectively.

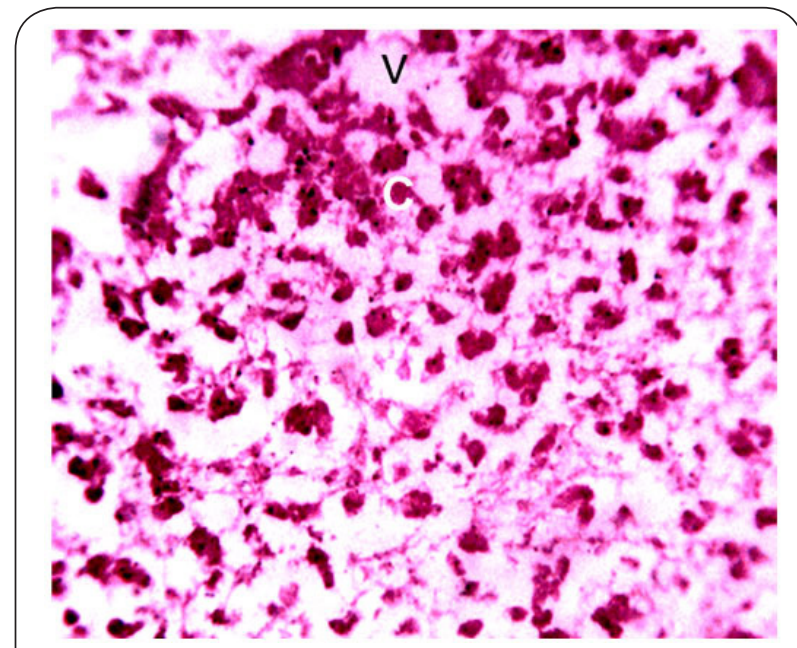

Plate 4. Photomicrograph of Liver of Clarias gariepinus obtained from Station 1 after 14 days bio-assay in River Galma at $x 400$. The letter $\mathbf{V}$ indicates vacoulation of the tissue. The letter $\mathbf{C}$ indicates constriction, hypertrophy and aggregation of hepatocytes.

there was congestion of blood vessels in the kidney of the fish. The severity of the damage was greater than what were observed in all the other stations in both kidney and liver of the fish exposed at this station. At station 5 however, the tissue alterations were minimal (Plates 9-11).

\section{Discussion}

Ecotoxicity assessment of River Galma was evident in the histopathological examination of fish tissues exposed in the river for a period of 14 days. Previous studies on River Galma

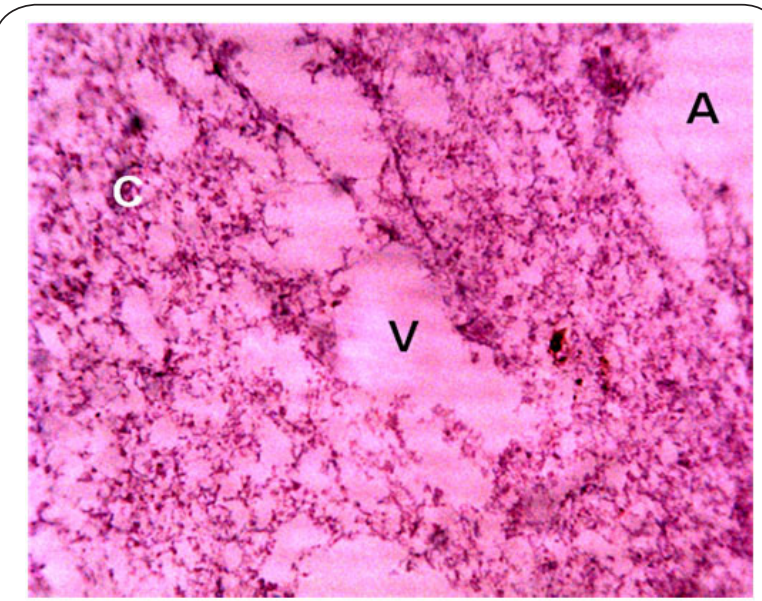

Plate 5. Photomicrograph of Kidney of Clarias gariepinus obtained from Station 2 after 14 days bio-assay in River Galma at $\mathrm{x} 400$. The letter $\mathbf{V}$ indicates severe vacoulation of the tissue. The letter $\mathbf{C}$ indicates constriction, hypertrophy and aggregation of cells. (A) stands for necrosis and infilteration of the cells.

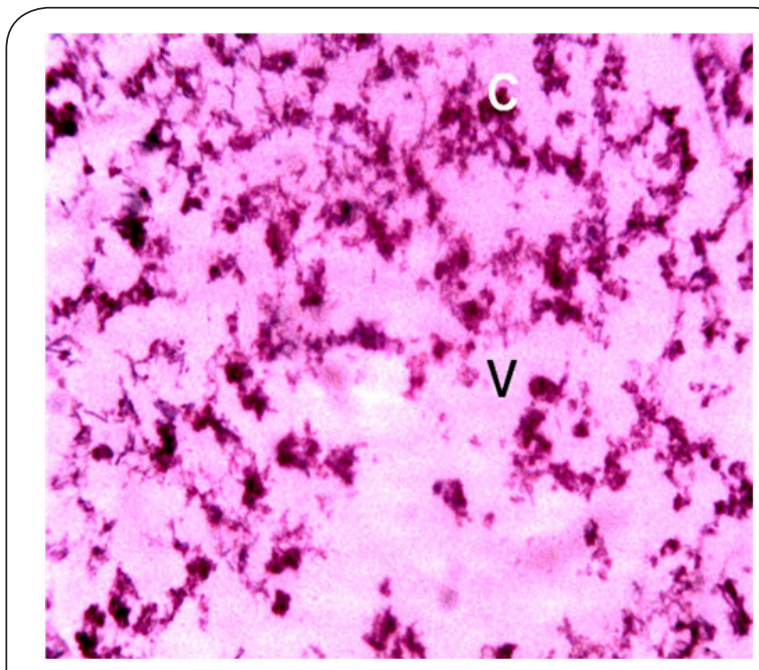

Plate 6. Photomicrograph of Liver of Clarias gariepinus obtained from Station 2 after 14 days bio-assay in River Galma at $x$ 400. The letter $\mathbf{V}$ indicates severe vacoulation and necrosis of the tissue. The letter $\mathbf{C}$ indicates constriction, hypertrophy and aggregation of hepatocytes. are indicative of the fact that the river is polluted [3,25-27] The results obtained from this research have demonstrated remarkable variations in alterations of the liver and kidney of Clarias gariepinus in situ bio-assay in River Galma from station to station along the stretch of the river. Polluted aquatic environment has myriads of sources through which pollutants enter the aquatic medium [9]. This is why a sustained monitoring of the aquatic environment is necessary because exposure to polluted water may adversely affect various organs in fish which ultimately could lead to overall 


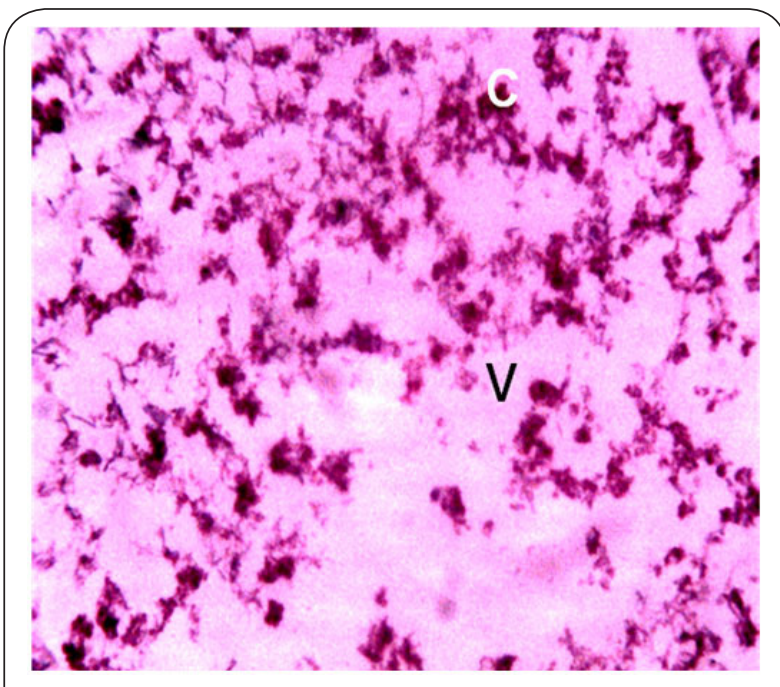

Plate 7. Photomicrograph of Kidney of Clarias gariepinus obtained from Station 3 after 14 days bio-assay in River Galma at X 400.The letter V indicates severe shattering, vacoulation and necrosis of the tissue. The letter $\mathrm{C}$ indicates constriction, hypertrophy and aggregation of cells.

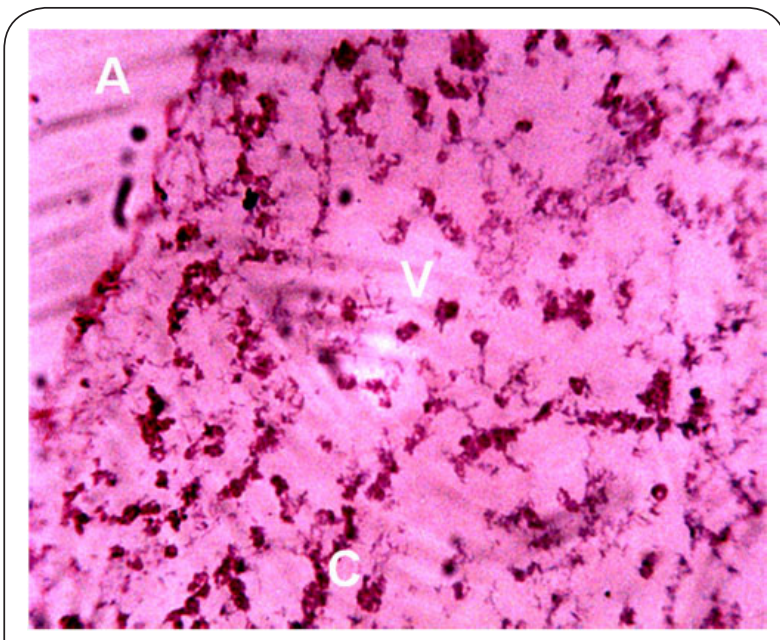

Plate 8. Photomicrograph of Liver of Clarias gariepinus obtained from Station 3 after 14 days bio-assay in River Galma at $x$ 400. The letter $\mathbf{V}$ indicates vacoulation of the tissue. The letter $\mathbf{C}$ indicates constriction and aggregation of hepatocytes.

toxic impact on organs like gill and liver $[12,13,21]$. This is why it is important to examine the toxic effects of metals on fish since they constitute an important link in food chain $[17,18]$ and causes imbalances in aquatic system [8].

Every station of the sampling points displayed alterations of the tissues of the fish. These alterations in comparison with the control (samples prior to exposure) ranged from constriction, aggregation and vacuolation of the cells of the

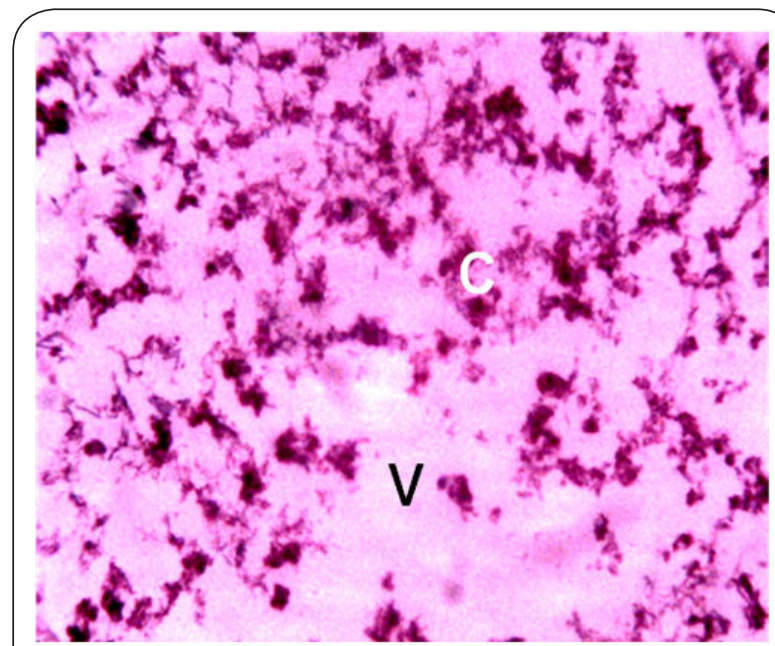

Plate 9. Photomicrograh of Kidney of Clarias gariepinus obtained from Station 4 after 14 days bio-assay in River Galma at $x$ 400. The letter $\mathbf{V}$ indicates severe shattering and vacoulation of the tissue. The letter $\mathbf{C}$ indicates constriction, hypertrophy and aggregation of cells.

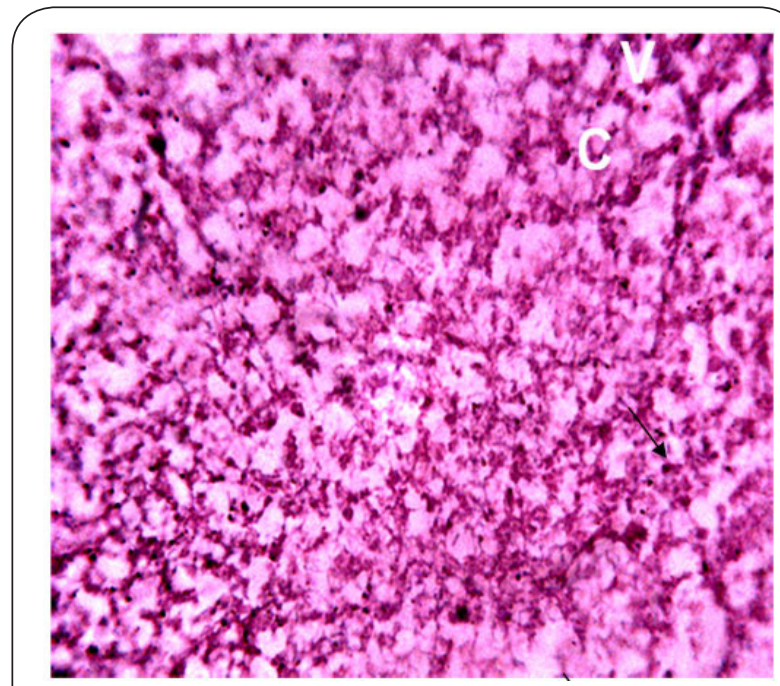

Plate 10. Photomicrograph of Liver of Clarias gariepinus obtained from Station 4 after 14 days bio-assay in River Galma at $x$ 400. The letter $\mathbf{V}$ indicates vacoulation of the tissue. (C) Indicates constriction and aggregation of cells. kidneys of the fish exposed in Stations 1 and 2. Hypertrophy of the cells was evident at $\times 400$ magnification (Plates 3 and 5). Similar alterations in the liver were also observed but more severe in the kidney than in the liver of the fish (Plates $\mathbf{4}$ and $\mathbf{6}$ ) exposed at these two stations where the river is not severely impacted by anthropogenic activities of the surrounding communities. However, Station 2 is where the direct discharge of wastes from neighbouring Sabon-Gari town was beginning 


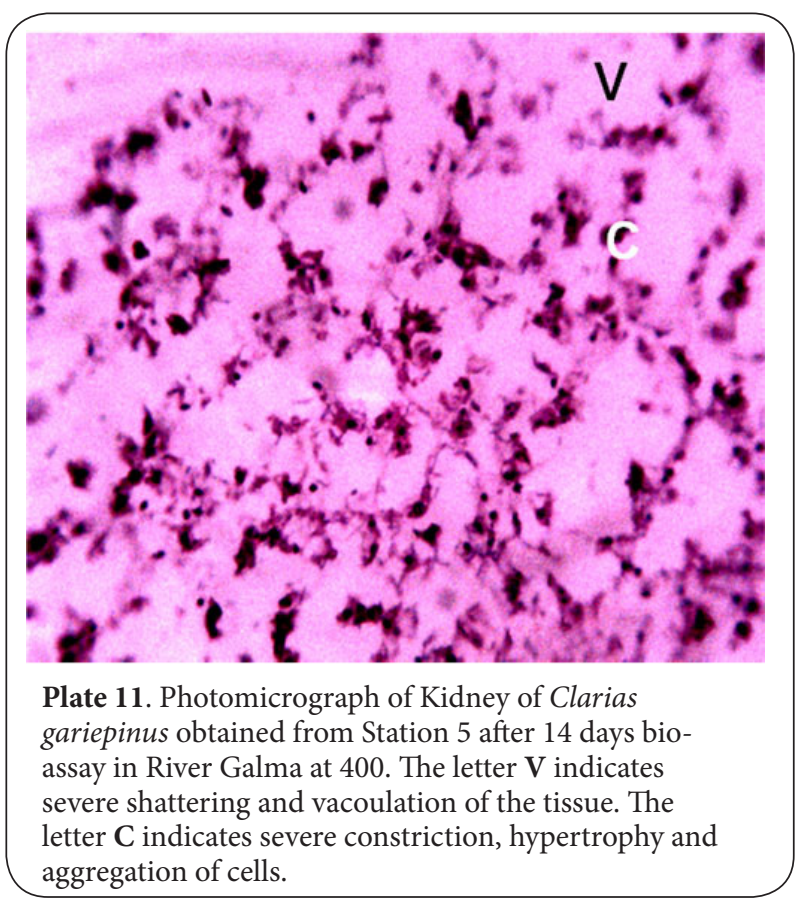

to have impact on the river ecosystem. That kidney, being the primary organ of detoxification was actively engaged in dealing with the xenobiotic from various sources was evident in the alterations of the architecture of kidney tissue (Plate 5). These findings agree with $[5,19]$ that metals which accumulate in kidneys damage filtering mechanisms and affect structure and ultra-structure. This result is also in conformity with the work of [22] that tissue histopathology, oxidative damage to biomolecules and modulation of antioxidant enzyme activity in carp and plant tissues exposed to River llova is the result of synergistic toxic effects of micro--pollutants present in the surface water.

The severity of alteration coupled with constriction, vacuolation, aggregation, hypertrophy, and necrosis of the tissues were more evident in Station 3, probably because it receives municipal wastes, effluents and agricultural run-offs from some parts of Sabon Gari, Chikaji, Kakeyi and Farin Kasa villages. Again, the architecture of the kidney was more severely damaged than that of the liver (Plate 7). These findings are similar to those of [15] on advancing hepatic necrosis in the liver of Clarias gariepinus exposed to 2, 4-D amine; and to histopathological changes in Liver of Clarias gariepinus Fish exposed to sub-lethal concentrations of Lead Nitrate and Crude Oil by [13].

Station 4, in addition to the usual alterations observed in other stations, had congestion of blood vessels in the kidney, with total destruction of the architecture of the tissues at $x 400$ magnification (Plate 9). The peculiar nature of this Station 4 which receives municipal wastes, effluents and agricultural run-offs from various parts of Tudun Wada, PZ, and Congo via Kubani stream may have accounted for the total destruction of the architecture of the tissues. Other workers $[4,13,19]$ reported major histopathological changes in liver which included loss of cellular architecture, necrosis in hepatocytes and accumulation of fat in parenchymal cells as well as congestion of blood vessels as obtained in this Station 4. [2] also demonstrated slightly similar results in mosquito fish's (Gambusia affinis) kidney and liver.

The tissue sections from Station 5 also displayed histopathological alterations, mainly vacuolation, constriction and aggregation of cells and hypertrophy (Plate 11). The river may have started self-purification at this down-stream section of the river course. These results lend support that histopathological biomarkers can be used as indicators for the effects of various anthropogenic pollutants on organisms and are a reflection of the overall health of the entire population in the ecosystem [14].

\section{Conclusion}

This study has shown varying alterations of the kidneys and livers of Clarias gariepinus exposed in situ for fourteen days at 5 Stations along River Galma. The major alterations ranged from vacuolation, constriction, necrosis, aggregation of the cells to congestion of the blood vessels. The severity of alterations especially in the kidneys vary from station to station as an indication that River Galma is experiencing pollution at different points along the river.

\section{Recommendations}

It is recommended that further studies incorporating the dry season should be carried out for adequate comparison with the rainy season effects. Also, the concentrations of heavy metals and other pollutants should be determined to help in evidence-base decision by relevant authorities to control further pollution of River Galma.

\section{Competing interests}

The authors declare that they have no competing interests.

Authors' contributions

\begin{tabular}{|l|c|c|c|c|}
\hline Authors' contributions & POS & JAA & BS & YJD \\
\hline Research concept and design & $\checkmark$ & $\checkmark$ & $\checkmark$ & -- \\
\hline Collection and/or assembly of data & $\checkmark$ & -- & -- & -- \\
\hline Data analysis and interpretation & $\checkmark$ & -- & -- & -- \\
\hline Writing the article & $\checkmark$ & -- & -- & -- \\
\hline Critical revision of the article & $\checkmark$ & $\checkmark$ & $\checkmark$ & -- \\
\hline Final approval of article & $\checkmark$ & $\checkmark$ & $\checkmark$ & $\checkmark$ \\
\hline Statistical analysis & $\checkmark$ & -- & -- & $\checkmark$ \\
\hline
\end{tabular}

\section{Acknowledgements}

Special thanks go to Mr. Wularikan Meslam of Fisheries Laboratory, Department of Biological Sciences, Ahmadu Bello University Zaria for his technical assistance and the fishermen that guarded the cages during the exposure period. We also thank Mr. Peter Akpulu of Human Anatomy Department, Ahmadu Bello University, Zaria for photomicrography of the tissue sections. 
Samuel et al. Applied Scientific Reports 2017,

Publication history

EIC: James A Radosevich, University of Illinois at Chicago, USA.

Received: 12-Dec-2016 Final Revised: 31-May-2017

Accepted: 10-Jul-2017 Published: 21-Jul-2017

\section{References}

1. Amaeze N. H, Onadeko A and Nwosu C. C. Comparative acute toxicity and oxidative stress responses in tadpoles of Amietophrynus regularis exposed to refined petroleum products, unused and spent engine oils. Afric. J. Biotech. 2014; 13:4251-4258. | Article

2. Annabi B, Vaillancourt-Jean E, Weil AG and Beliveau R. Pharmacological targeting of beta-adrenergic receptor functions abrogates NF-kappaB signaling and MMP-9 secretion in medulloblastoma cells. Onco Targets Ther. 2010; 3:219-26. | Article | PubMed Abstact | PubMed FullText

3. Butu A.W, Bichi A. A. Assessment of some heavy elements in Galma dam, Zaria, Nigeria. Int. J. Devel. Sust. 2013; 2:686-696. I Pdf

4. Chavan V. R and Mulley D. V. Effects of heavy metals on liver and gill of fish Cirrhinus mrigala. Int. J. Curr. Microbiol. Apld Sci. 204; 3:277-288.

5. Costa PM, Caeiro S and Costa MH. Multi-organ histological observations on juvenile Senegalese soles exposed to low concentrations of waterborne cadmium. Fish Physiol Biochem. 2013; 39:143-58. I Article | PubMed

6. Diffenbaugh NS and Field CB. Changes in ecologically critical terrestrial climate conditions. Science. 2013; 341:486-92. | Article | PubMed

7. Edward J. B, Idowu E. O, Oso J. A and Ibidapo O. R. Determination of heavy metal concentration in fish samples, sediments and water from Odo-Ayo River in Ado-Ekiti, Ekiti-State, Nigeria. Int. J. Environ. Monit. Anal. 2013; 1:27-33. | Article

8. Firat $\mathrm{O}$ and Kargin F. Biochemical alterations induced by $\mathrm{Zn}$ and $\mathrm{Cd}$ individually or in combination in the serum of Oreochromis niloticus. Fish Physiol Biochem. 2010; 36:647-53. | Article | PubMed

9. Campos-Garcia J, Martinez DS, Alves OL, Leonardo AF and Barbieri E. Ecotoxicological effects of carbofuran and oxidised multiwalled carbon nanotubes on the freshwater fish Nile tilapia: nanotubes enhance pesticide ecotoxicity. Ecotoxicol Environ Saf. 2015; 111:131-7. | Article | PubMed

10. Ginebreda A, Kuzmanovic M, Guasch H, de Alda ML, Lopez-Doval JC, Munoz I, Ricart M, Romani AM, Sabater S and Barcelo D. Assessment of multi-chemical pollution in aquatic ecosystems using toxic units: compound prioritization, mixture characterization and relationships with biological descriptors. Sci Total Environ. 2014; 468-469:715-23. Article | PubMed

11. Haylamicheal I. D and Moges A. "Assessing Water Quality of Rural water Supply Schemes as a measure of Service delivery sustainability", A Case Study of Wondo Genet District, Southern Ethiopia". Afric. J. Environ. Sci. Techn., 2012; 6:229-236. I Pdf

12. Ikeogu C. F, Nsofor C. I, Ikpeze O. O, Nwuba L. A, Ezeasor D. N and Nwaogu I. C. Histopathological Alterations in Gills of Catfish and Changes in Aquarium pH, Temperature and Dissolved Oxygen due to Lead Nitrate and Crude Oil. Adv. Biores. 2016; 7:35-40.

13. Ikeogu C. F, Nsofor C. I, Ezeasor D. N, Ikpeze O. O and Nwaogu I. C. Histopathological Changes in Liver of Clarias gariepinus Fish exposed to sub-lethal concentrations of Lead Nitrate and Crude Oil. Adv. Biores, 2016; 7:41-45.

14. Khoshnood Z, Khodabandeh S, Mosafer S and Khoshnood R. "Effects of Cortisol on Gill Chloride Cells in Persian Sturgeon, Acipenser persicus, Fry." Yakhteh. 2010; 11:424-431.

15. Makinde G. E. O, Olaifa F. E and Banjo O. T. Acute Toxicity and Histopathological Changes in Gill and Liver of catfish (Clarias gariepinus) Juvenile exposed to 2, 4-D Amine (Herbex D SI). J. Biol., Agric. Healthcare. 2015; 5:145-150.
16. Merciai R, Guasch H, Kumar A, Sabater S and Garcia-Berthou E. Trace metal concentration and fish size: variation among fish species in a Mediterranean river. Ecotoxicol Environ Saf. 2014; 107:154-61. | Article I PubMed

17. Nsofor C.I and Ikpeze O.O. Potential Health Hazards of consuming Clarias gariepinus fish contaminated with heavy metals of River Niger Global Journal of Biology, Agriculture \& Health Sciences. 2014; 3:69-74.

18. Nsofor C. I, Igwilo I. O, Ikpeze O. O, Ikeogu C. F, Umeoguagu F. O and Okonkwo C. J. Bioaccumulation of heavy metals in Shellfish Macrobrachium rosenbergi in Niger River at Onitsha, Anambra State, Nigeria. Inter J Agri Biosci. 2014; 3:38-40.

19. Nsofor C.I, Ikpeze O. O, Ngenegbo U. C, Ikeogu, C. F and Okonkwo J. C. Histopathological Alterations in the Liver and Kidney of the Fish Chrysichthys nigrodigitatus due to Heavy Metals in Niger River. Journal of Natural Sciences Research. 2014; 4:11-18.

20. Omar WA, Saleh YS and Marie MA. Integrating multiple fish biomarkers and risk assessment as indicators of metal pollution along the Red Sea coast of Hodeida, Yemen Republic. Ecotoxicol Environ Saf. 2014; 110:221-31. | Article | PubMed

21. Parvathi A, Sivakumari P and Sarasu C. Effect of Chromium on Histological Alteration of Gill, Liver and Kidney of Freshwater Teleost, Cyprinus capio (L.)" J.Fish. Int. 2011; 6:1-5. | Article

22. Radic S, Gregorovic G, Stipanicev D, Cvjetko P, Srut M, Vujcic V, Orescanin $\mathrm{V}$ and Vinko Klobucar $\mathrm{GI}$. Assessment of surface water in the vicinity of fertilizer factory using fish and plants. Ecotoxicol Environ Saf. 2013; 96:32-40. | Article | PubMed

23. Sadia A, Feroza H. W, Imran Q, Muhammad H. S.W, Tirmizi S. A, Muhammad A. Q. Monitoring of anthropogenic influences on underground and surface water quality of Indus River at district Mianwali-Pakistan. Turk. J. Biochem. 2016; 38:25-30. I Pdf

24. Saleh YS and Marie MA. Assessment of metal contamination in water, sediment, and tissues of Arius thalassinus fish from the Red Sea coast of Yemen and the potential human risk assessment. Environ Sci Pollut Res Int. 2015; 22:5481-90. | Article | PubMed

25. Samuel P. O, Adakole J. A and Suleiman B. Temporal and Spatial PhysicoChemical Parameters of River Galma, Zaria, Kaduna State, Nigeria. Res and Environ, 2015; 5:110-123. | Article

26. Samuel P.O, Adakole J. A and Suleiman B. Effects of Some Heavy Metal Pollutants on Vitamin C and E Production In Clarias gariepinus (Burchell, 1822) In in situ Bio-Assay In River Galma, Kaduna State, Nigeria. J Environ Earth Sci. 2015; 16:10-27.

27. Samuel P. O, Adakole J. A and Suleiman B. Effects of Some Heavy Metal Pollutants on Glutathione Production In Clarias gariepinus (Burchell, 1822) In In Situ Bio-Assay In River Galma, Kaduna State, Nigeria. J Med, Physiol Biophy. 2015; 17:115-144.

28. Sfakianakis DG, Renieri E, Kentouri M and Tsatsakis AM. Effect of heavy metals on fish larvae deformities: A review. Environ Res. 2015; 137:24655. | Article | PubMed

29. Singh L. B. River pollution. 1st Edn. New Delhi: APH Publishing. ISBN-10: 8131300854. 2007; 192.

30. Storelli MM, Storelli A, D'Addabbo R, Marano C, Bruno R and Marcotrigiano GO. Trace elements in loggerhead turtles (Caretta caretta) from the eastern Mediterranean Sea: overview and evaluation. Environ Pollut. 2005; 135:163-70. | Article | PubMed

31. Suruchi K and Khanna P. Assessment of heavy metal contamination in different vegetables grown in and around urban areas. Res. J. Environ. Toxicol. 2011; 5:162-179. | Pdf

32. UNICEF/WHO. "Progress on drinking water and sanitation: 2012 update. WHO/UNICEF Joint Monitoring Programme for water supply and sanitation". UNICEF. New York. 2012. | Website

33. Vorosmarty CJ, Mclntyre PB, Gessner MO, Dudgeon D, Prusevich A, 
Samuel et al. Applied Scientific Reports 2017,

http://www.hoajonline.com/journals/pdf/2054-9903-4-1.pdf

Green P, Glidden S, Bunn SE, Sullivan CA, Liermann CR and Davies PM.

Global threats to human water security and river biodiversity. Nature.

2010; 467:555-61. | Article | PubMed

34. Yaji A. J and Auta J. Sublethal effects of monocrotophos on some hematological indices of African catfish Clarias gariepinus (Teugels). J. fish Int. 2007; 2:115-117. | Article

35. Zaki M. S, Authman M. M. N, Hammam A. M. M and Shalaby S. I. Aquatic environmental pollution in the Egyptian countryside and its effect on fish production (Review). Life Sci. J. 2014; 11:1024-1029. | Pdf

\section{Citation:}

Samuel PO, Adakole JA, Suleiman B and J. D Y.

Histopathological alterations in kidney and liver of Clarias gariepinus (burchell, 1822) studied in river galma, Nigeria. Appl Sci Rep. 2017; 4:1.

http://dx.doi.org/10.7243/2054-9903-4-1 